\title{
OPTIMALISASI PENGGUNAAN LEMBAR KERJA SISWA (LKS) TERSTRUKTUR UNTUK MENINGKATKAN AKTIVITAS DAN HASIL BELAJAR EKONOMI SISWA KELAS X-3 SMA NEGERI 2 BUSUNGBIU
}

\author{
Putu Agus Eka Sedana Jaya \\ SMA Negeri 2 Busungbiu \\ Busungbiu, Indonesia \\ e-mail : aguseka.gosi@gmail.com
}

\begin{abstract}
Abstrak
Penelitian ini bertujuan meningkatkan aktivitas dan hasil belajar dengan penggunaan LKS terstruktur dalam pembelajaran ekonomi. Jenis penelitian ini adalah penelitian tindakan kelas yang dilaksanakan dalam dua siklus. Subjek penelitian adalah siswa kelas X-3 semester ganjil SMA Negeri 2 Busungbiu Tahun Pelajaran 2012/2013. Data yang dikumpulkan dalam penelitian ini adalah aktivitas dan hasil belajar ekonomi. Data aktivitas diperoleh dengan melakukan observasi. Data hasil belajar diperoleh dengan menggunakan tes hasil belajar siswa. Selanjutnya data yang terkumpul dalam penelitian ini dianalisis dengan analisis deskriptif. Hasil penelitian menunjukkan : (1) aktivitas belajar siswa meningkat dari skor rata-rata 66,70 dengan kategori cukup pada siklus I menjadi skor rata-rata 83,18 dengan kategori baik pada siklus II, (2) hasil belajar siswa meningkat dari skor rata-rata 62,14 pada siklus I menjadi skor rata-rata 66,36 dan ketuntasan belajar klasikalnya meningkat dari $68 \%$ pada siklus I menjadi $79 \%$ pada siklus II. Dengan demikian, optimalisasi penggunaan LKS terstruktur dapat meningkatkan aktivitas dan hasil belajar siswa.
\end{abstract}

Kata-kata kunci : LKS terstruktur, aktivitas, hasil belajar

\begin{abstract}
This research aimed at improving the activities and the result study by the use of Structured Students' Worksheet in Teaching and learning Economy subject. This research is Action Based Research that was done into two cycles. The subjects of the research are the first semester students of class X3 of SMA N Busungbiu in the academic year 2012/2013. The data that were gathered in this research were the activities and the result study of Economy subject. The data was obtained by doing observation. The result study data was obtained by testing the students. Then the data which was gathered in this research was analyzed descriptively. The result of the study shows that : (1) The students' activity in teaching and learning process increase from the mean score 66,70 which can be categorized as average in cycle 1 to be the mean score of 83,18 which can be categorized as good in cycle II, (2) The result study of the students increase from the mean score 62,14 in cycle I to be the mean score 66,36 and the classical learning achievement increase from $68 \%$ in cycle I to be $79 \%$ in cycle II. Therefore, the optimization of the use of structured Students' worksheet can improve the activities and the students' result study.
\end{abstract}

Keyword : structured students' worksheet, activities, result study

\section{PENDAHULUAN}

Suatu pendidikan sekolah selalu diawali dengan adanya input yaitu siswa. Input ini kemudian menjalani proses pendidikan yang dilakukan oleh sekolah dengan pengaruh berbagai faktor dalam lingkungan. Setelah proses dilakukan, dihasilkan output pendidikan yaitu siswa yang telah mengalami pendidikan 
sekolah. Lebih jauh lagi, dari output pendidikan tersebut dituntut adanya outcome berupa kemampuan lebih yang diharapkan dimiliki oleh siswa setelah siswa menjalani proses pendidikan.

Setiap siswa yang merupakan input pendidikan memiliki potensi yang sama untuk dikembangkan. Namun, pada kenyataannya kualitas siswa yang merupakan output pendidikan berbeda-beda. Perbedaan kualitas tersebut dikarenakan oleh dua faktor, yaitu faktor internal dan faktor eksternal. Faktor internal adalah faktor-faktor dalam diri siswa diantaranya minat dan motivasi. Faktor eksternal adalah faktor lingkungan yang mempengaruhi proses pendidikan yaitu kurikulum, metode pembelajaran yang diterapkan guru, fasilitas belajar yang disediakan sekolah, dan media pembelajaran yang digunakan oleh guru. Faktor eksternal dapat mempengaruhi faktor internal. Sebagai contoh, media pembelajaran berupa bahan ajar yang menarik mampu menimbulkan minat siswa terhadap suatu pelajaran.

Walaupun pemerintah telah berupaya menciptakan lingkungan pendidikan yang kondusif agar tercipta proses pendidikan yang berkualitas demi dihasilkan output pendidikan yang berkualitas, kenyataan di beberapa sekolah masih menunjukkan hasil yang kurang memuaskan. Hal ini terjadi pada siswa-siswa kelas X-3 SMA Negeri 2 Busungbiu. Proses belajar mengajar di kelas ini masih menunjukkan hasil yang kurang memuaskan. Salah satu indikator yang mencerminkan fenomena tersebut adalah hasil belajar siswa kelas X-3 pada mata pelajaran ekonomi semester genap tahun pelajaran 2011/2012 sangat kurang dibandingkan dengan kelas yang lainnya menunjukkan rata-rata nilai
52,5 dengan rentang nilai dari 0 sampai 100, serta ketuntasan klasikal 53\%. Rendahnya hasil rerata ini menunjukkan bahwa hasil belajar pada mata pelajaran Ekonomi masih belum memenuhi apa yang diharapkan sebelumnya. Hal ini tentunya dapat dijadikan cerminan bagi praktisi pendidikan bahwa masih banyak yang perlu diperbaiki pada lingkungan pendidikan, dengan demikian peneliti melakukan pre test untuk mengetahui hasil belajar siswa kelas X3 pada semester ganjil tahun pelajaran 2012/2013. Pre test ini dikuti oleh 28 siswa dengan jumlah 20 soal pilihan ganda. Dan setelah dianalisis hasilnya hanya mencapai rata-rata sebesar 21,79 dengan ketuntasan belajar sebesar $0 \%$ dan daya serap mencapai $22 \%$.

Berdasarkan hasil observasi awal dan pre test di kelas X-3 SMA Negeri 2 Busungbiu, maka ada beberapa hal yang diidentifikasi sebagai faktor penyebab rendahnya hasil belajar siswa yaitu sebagai berikut.Pertama, guru dalam menggunakan metode diskusi masih belum efektif, karena siswa dibiarkan berdiskusi sebatas pada pertanyaan yang diajukan oleh guru. Informasi masih bersifat satu arah, yaitu dari guru kepada siswa, mereka berdiskusi tidak diarahkan dengan baik karena kurangnya media untuk menunjang kegiatan diskusi. Kedua, partisipasi aktif siswa dalam proses belajar mengajar masih kurang. Siswa jarang memberikan pertanyaan, siswa jarang mengemukakan pendapat, siswa jarang berinteraksi dengan guru, siswa jarang berinteraksi dengan siswa lainnya. Hal ini salah satunya diakibatkan oleh kurangnya bahan yang digunakan dalam berdiskusi. Ketiga, siswa jarang mempresentasikan hasil pekerjaannya. Sehingga, sulit diketahui sampai sejauh mana 
pemahaman siswa terhadap materi yang diajarkan. Sistem pengujian bersifat tes tulis yang hanya mengindikasikan sebagian kemampuan kognitif saja, tidak dapat mengindikasikan kemampuan sebenarnya dari siswa baik dalam hal kognitif apalagi kemampuan afektif dan psikomotor siswa. Keempat, kurangnya bahan ajar yang digunakan dalam menunjang kegiatan pembelajaran. Bahan ajar yang mampu menuntun siswa untuk mengeksplorasi informasi yang disediakan sehingga mampu mengelaborasi guna mendapatkan konsep dalam materi pembelajaran. Bahan ajar yang berpola secara terstruktur dalam sebuah LKS menggiring siswa untuk melakukan diskusi dengan teman kelompoknya.

Berdasarkan uraian permasalahan yang terungkap tersebut, kegiatan diskusi yang dilakukan oleh guru tidak berjalan dengan baik, siswa kurang mampu mengekspresikan dirinya, baik dalam menjawab pertanyaan maupun dalam mempresentasikan hasil pekerjaannya. Oleh karena itu perlu adanya upaya penyempurnaan proses pembelajaran guna menunjang kegiatan diskusi yang dilakukan oleh guru, sehingga mampu mengubah paradigma pembelajaran yang sebelumnya berpusat pada guru (teacher center oriented) di mana menempatkan guru sebagai pusat dari segala informasi menjadi pembelajaran yang berpusat pada siswa (student center oriented) di mana guru diposisikan sebagai fasilitator yang memfasilitasi siswa dalam proses belajar mengajar.

Sehubungan dengan hal tersebut, maka dipandang penting untuk menyediakan bahan ajar yang efektif dan sesuai dengan indikator ketercapaian kompetensi. Bahan ajar yang dimaksud berupa lembar kerja siswa (LKS) yang disusun secara terstruktur. LKS terstruktur membantu guru dalam menerapkan metode diskusi dengan baik, LKS terstruktur ini memberikan media kepada siswa untuk mengeksplorasi semua informasi yang disediakan untuk mengelaborasi konsep maupun fakta materi pelajaran yang diajarkan dalam kegiatan pembelajaran.

Berdasarkan uraian pada latar belakang di atas, maka dapat dirumuskan permasalahan sebagai berikut : 1) Apakah penggunaan LKS Terstruktur dalam pembelajaran Ekonomi dapat meningkatkan aktivitas siswa kelas X3 SMA Negeri 2 Busungbiu? 2) Apakah penggunaan LKS Terstruktur dalam pembelajaran Ekonomi dapat meningkatkan hasil belajar siswa kelas X3 SMA Negeri 2 Busungbiu?. Sehingga tujuan penelitian ini adalah : 1) Meningkatkan aktivitas siswa dalam pembelajaran Ekonomi melalui optimalisasi penggunaan LKS Terstruktur. 2) Meningkatkan hasil belajar siswa dalam pembelajaran Ekonomi melalui optimalisasi penggunaan LKS Terstruktur. Adapun manfaat yang diharapkan dari hasil penelitian ini adalah sebagai berikut : 1) bagi sekolah, hasil penelitian ini diharapkan dapat menjadi salah satu bahan pertimbangan dalam penerapan berbagai bahan ajar di sekolah. Bahan ajar ini diharapkan dapat dikembangkan dalam pembelajaran bidang studi lainnya. 2) bagi guru ekonomi, hasil penelitian ini dapat digunakan sebagai salah satu alternatif dalam memilih bahan ajar yang cocok untuk dikembangkan dan hasil penelitian ini diharapkan dapat menjadi salah satu bacaan bagi guru bidang studi utamanya guru bidang studi ekonomi guna menambah pengetahuan tentang optimalisasi penerapan baham ajar yang lainnya dalam pembelajaran, situasi yang seringkali terjadi di kelas, serta alternatif solusi yang dapat 
diterapkan pada situasi kelas yang dimaksud. 3) bagi siswa, penelitian ini memberikan pengalaman belajar yang baru yang mungkin belum pernah dialami oleh siswa yang biasanya mengalami proses belajar mengajar konvensional, penelitian ini juga memberikan pelajaran kepada siswa untuk dapat hidup dalam suasana sosial dan demokratis di dalam kelas, saling tukar informasi, dan saling membantu antar siswa sehingga pada proses pembelajaran dapat berlangsung lebih bermakna, menarik, dan efektif.

\section{METODE}

Jenis penelitian yang dilakukan adalah penelitian tindakan kelas (classroom action research). Subjek dari penelitian ini adalah siswa kelas X-3 Semester Ganjil SMA Negeri 2 Busungbiu Tahun Pelajaran 2012/2013 yang berjumlah 28 orang dan objek dari penelitian ini adalah peningkatan aktivitas dan hasil belajar siswa setelah diterapkan penggunaan LKS Terstruktur. Penelitian ini dibagi dalam dua siklus dengan masing-masing siklus terdiri dari empat tahapan yaitu: (1) perencanaan, (2) tindakan, (3) observasi/evaluasi, dan (4) refleksi.

Tahap perencanaan dilakukan dengan tindakan mempersiapkan perangkat pembelajaran dan LKS terstruktur yang akan diberikan pada setiap pertemuan. Tahap pelaksanaan tindakan meliputi : pengelolaan kelas berdasarkan RPP, memberikan media pembelajaran berupa bahan ajar LKS terstruktur, pelaksanaan pembelajaran yang menitikberatkan pada kegiatan eksplorasi, elaborasi dan konfirmasi yang terdapat dalam LKS terstruktur. Pada tahap observasi/evaluasi dilakukan tindakan pengamatan pada aktivitas siswa dan pelaksanaan evaluasi berupa tes untuk hasil belajar siswa, sedangkan pada tahap refleksi meliputi kegiatan perbaikan dalam proses pembelajaran dan persiapan kembali untuk pelaksanaan siklus selanjutnya berdasarkan rata-rata aktivitas dan hasil belajar yang dibandingkan dengan indikator keberhasilan kinerja.

Dalam mengukur hasil belajar dan aktivitas siswa digunakan teknik pengumpulan data seperti yang terlihat pada tabel 1 di bawah ini.

Tabel 1. Teknik Pengumpulan Data

\begin{tabular}{|c|c|c|c|c|}
\hline No & Jenis Data & $\begin{array}{c}\text { Sumber } \\
\text { Data }\end{array}$ & Instrumen Penelitian & Waktu \\
\hline 1 & $\begin{array}{l}\text { Aktivitas } \\
\text { Siswa }\end{array}$ & Siswa & $\begin{array}{l}\text { Lembar observasi } \\
\text { aktivitas siswa }\end{array}$ & $\begin{array}{l}\text { Setiap } \\
\text { pertemuan }\end{array}$ \\
\hline 2 & $\begin{array}{l}\text { Hasil } \\
\text { Belajar }\end{array}$ & Siswa & $\begin{array}{l}\text { Tes } \\
\text { Ulangan harian }\end{array}$ & $\begin{array}{l}\text { setiap akhir } \\
\text { siklus }\end{array}$ \\
\hline
\end{tabular}

Data aktivitas siswa dianalisis berdasarkan skor yang diperoleh sesuai hasil observasi. Hasil yang diperoleh disesuaikan dengan pedoman penggolongan sikap siswa yang selanjutnya dapat dinyatakan dengan Tabel 2 
Tabel 2. Pedoman Penggolongan Aktivitas Siswa

\begin{tabular}{rcc}
\hline No & Skor & Kategori \\
1 & $86-100$ & Amat Baik \\
2 & $76-85$ & Baik \\
3 & $66-75$ & Cukup \\
4 & $\leq 65$ & Kurang \\
\hline
\end{tabular}

Penelitian tindakan kelas ini dikatakan berhasil apabila skor aktivitas siswa minimal berada pada kualifikasi Baik pada akhir siklus II. Sedangkan data hasil belajar diperoleh dengan memberikan tes pada setiap akhir siklus dan kemudian dianalisis secara deskriptif untuk menentukan skor rata-rata kelas dan ketuntasan belajar. Siswa dikatakan tuntas jika DSS $\geq 65 \%$ dan $\mathrm{KK} \geq 75 \%$. Hal ini sesuai dengan kriteria yang ditetapkan oleh SMA Negeri 2 Busungbiu. Penelitian dikatakan berhasil jika skor rata-rata kognitif siswa ( $\overline{\mathrm{X}}$ kognitif) $\geq 65$ dan ketuntasan klasikal $(\mathrm{KK}) \geq 75 \%$.

\section{HASIL DAN PEMBAHASAN}

Hasil penelitian yang dilaksanakan pada Siklus siswa yaitu diperoleh rata-rata keseluruhan aktivitas siswa sebesar 66,70 dengan kategori Cukup (C). Sedangkan untuk Nilai Hasil Belajar Siswa pada Siklus I diperoleh nilai keseluruhan siswa sebesar 1.740 dengan rata-rata hasil belajar mencapai 62,14.

Hasil aktivitas belajar siswa yang menunjukkan rata-rata 66,70 dengan kategori Cukup (C) ini sebenarnya merupakan gambaran keseluruhan siswa kelas X-3 pada siklus I, pada siklus ini siswa masih belum mengerti akan ketersediaan LKS Terstruktur dan pola kegiatan yang dilakukan dalam berdiskusi. Siswa masih mengandalkan teman yang lainnya untuk mengeksplorasi maupun mengelaborasi LKS yang diberikan. Gambaran aktivitas siswa masih jauh dari harapan di mana masih banyak siswa yang mendapatkan kategori Kurang (K) dalam beraktivitas utamanya menganalisis dan mengerjakan LKS Terstruktur yang diberikan.

Selain itu pada siklus I nilai hasil belajar siswa juga tidak mencerminkan indikator kinerja yang diharapkan di mana nilai belajar siswa secara klasikal masih mencapai rata-rata 62,14. Hasil yang didapat ini jika dilihat dari indikator kinerja masih dibawah yang semestinya harus mencapai ratarata 65. Untuk ketuntasan belajar yang dilihat dari perbandingan pencapaian KKM juga masih dibawah harapan dimana dari data sebaran pencapaian hasil belajar siswa ketuntasan hanya mencapai $68 \%$.

Dengan hasil ini menunjukkan adanya kelemahan dalam penerapan LKS terstruktur untuk pencapaian aktivitas dan hasil belajar mata pelajaran Ekonomi, sehingga dengan kendala ini diupayakan berbagai perbaikan yang akan dilaksakan pada siklus II baik dari cara pembuatan LKS Terstruktur maupun pola penerapannya dalam kegiatan pembelajaran. LKS terstruktur yang disusun lebih sederhana lagi dengan pemahaman yang mendasar agar pola kegiatan eksplorasi dalam menyimak dan mengidentifikasi permasalahan dapat dipahami. Begitu juga dengan kegiatan elaborasi yang menuntun siswa untuk menyimpulkan konsep dan identifikasi informasi dapat dilakukan dengan baik. 
Hasil penelitian yang
dilaksanakan pada Siklus II
didapatkan hasil aktivitas belajar
siswa yang terlampir pada
pertemuan I sampai dengan pertemuan III yaitu diperoleh ratarata keseluruhan aktivitas siswa sebesar 83,18 dengan kategori Baik (B). Sedangkan untuk Nilai Hasil Belajar Siswa yang terlampir pada Siklus II dari pertemuan I sampai dengan pertemuan III diperoleh nilai keseluruhan siswa sebesar 1.830 dengan rata-rata hasil belajar mencapai 66,36.

Hasil aktivitas belajar siswa yang menunjukkan rata-rata 83,18 dengan kategori Baik (B) ini merupakan gambaran keseluruhan siswa kelas X-3 pada siklus II, pada siklus II ini aktivitas siswa mengalami kenaikan sebesar 16,49 dari siklus I yang sebesar 66,70 atau naik sebesar $20 \%$ dari kategori Cukup (C) pada siklus I menjadi kategori Baik (B) pada siklus II. Gambaran hasil pada siklus II ini menunjukan hasil yang signifikan dari perbaikan kelemahankelemahan yang ada pada siklus II seperti perbaikan LKS Terstruktur yang diberikan serta pengelolaan kelas dalam berdiskusi dan menyelesaikan LKS Terstruktur yang diberikan kepada siswa. Dengan perbaikan ini siswa tidak lagi merasa terbeban dan susah dalam menyelesaikan LKS Terstruktur yang diberikan. Siswa lebih mudah dalam mengekplorasi dan mengelaborasi LKS Terstruktur tersebut.

Nilai hasil belajar siswa pada mata pelajara Ekonomi pada siklus II mencapai diperoleh nilai keseluruhan siswa sebesar 1.830 dengan rata-rata hasil belajar mencapai 66,36 . Pada siklus II ini nilai keseluruhan hasil belajar siswa mengalami kenaikan sebesar 90,00 dari yang sebelumnya sebesar 1.740 pada siklus I. Rata-rata hasil belajar siswa juga mengalami kenaikan sebesar 3,21 dari siklus I sedangkan ketuntasan belajar siswa keseluruhan yang mencapai $79 \%$ pada siklus II naik sebesar $11 \%$ yang sebelumnya mencapai $68 \%$ pada siklus I. Kenaikan hasil belajar siswa pada mata pelajaran Ekonomi ini sangatlah signifikan dengan perbaikan yang dilakukan pada siklus II. Dengan demikian hasil yang didapatkan ini memberikan keyakinan bagi peneliti bahwa penerapan LKS Terstruktur dalam berbagai situasi pembelajaran dapat meningkatkan aktivitas dan hasil belajar siswa dan kenaikan yang didapatkan pada siklus II ini juga menjadi gambaran sebuah upaya yang maksimal bagi peneliti guna meningkatkan proses pembelajaran dan mutu pendidikan di SMA Negeri 2 Busungbiu.

\section{SIMPULAN DAN SARAN}

Berdasarkan hasil penelitian dan pembahasan maka dapat disimpulkan beberapa hal sebagai berikut : 1) Optimalisasi penerapan LKS Terstruktur dapat meningkatkan aktivitas siswa kelas $\mathrm{X}-3$ pada semester ganjil Tahun Pelajaran 2012/2013 hal ini dapat dilihat dari kenaikan aktivitas siswa yang mencapai kategori Baik (B) yang sebelumnya berada dalam kategori Cukup (C), 2) Optimalisasi penerapan LKS Terstruktur dapat meningkatkan hasil belajar siswa kelas X-3 pada semester ganjil Tahun Pelajaran 2012/2013 hal ini ditunjukkan dengan adanya jumlah siswa yang tuntas sebanyak 0 siswa pada refleksi awal menjadi 19 siswa pada siklus I dan meningkat menjadi 22 orang pada siklus II, 3) Peningkatan aktivitas dan hasil belajar pada mata pelajaran Ekonomi merupakan pembuktian dari tujuan penelitian yang sudah ditetapkan, serta menjadi pencapaian bagi peneliti atas upaya maksimal yang dilakukan dalam meningkatkan mutu pendidikan di SMA Negeri 2 Busungbiu 
Adapun saran-saran yang ingin diajukan peneliti sesuai dengan hasil penelitian ini adalah : 1) optimalisasi Penggunaan LKS Terstruktur ini menjadi salah satu upaya dalam meningkatkan profesionalisme guru dalam membuat bahan ajar dan melakukan sebuah penelitian bagi keberhasilan produk yang dihasilkan, 2) disarankan kepada guru lainnya untuk merubah paradigma teacher centered menjadi student centered, serta merubah paradigma guru dari guru sebagai pusat informasi menjadi guru sebagai fasilitator dan mediator pembelajaran, 3) kepada peneliti selanjutnya, disarankan untuk mengadakan penelitian lebih lanjut dan semoga hasil penelitian ini dapat berguna untuk menunjang penelitian selanjutnya.

\section{DAFTAR PUSTAKA}

Badan Standar Nasional Pendidikan 2006. Panduan Penyusunan Kurikulum Tingkat Satuan Pendidikan Jenjang Pendidikan Dasar Dan Menengah Jakarta: BNSP

Lie, Anita. 2002. Cooperative learning Mempraktikkan Cooperative learning di Ruang-Ruang Kelas. Jakarta: Penerbit PT Gramedia Widiasarana Indonesia.

Robith, A. S. dan Hartanto, J. S.. 1995. Kamus Lengkap 555.000.000 Inggris-Indonesia Indonesia-Inggris. Suranaya: Penerbit Indah.

Santiani, N. K. 2005. Efektifitas Model pembelajaran Kooperatif tipe Teams-GamesTournament (TGT) dalam Pembelajaran di SMP Negeri 3 Singaraja tahun ajaran 2004/2005 (Studi Kuasi Eksperimen dalam Pembelajaran Listrik Magnet). Skripsi. Tidak diterbitkan. Jurusan Pendidikan Fisika, IKIP Negeri Singaraja.
Sulistiarmi, Nyoman 2006. Optimalisasi Penggunaan Lembar Kerja Siswa dengan Pendekatan Konstruktivis dalam Meningkatkan Prestasi Belajar Matematika Siswa Kelas VII D SMP Negeri 1 Sukasada. Skripsi. Tidak diterbitkan. Jurusan Pendidikan Matematika, IKIP Negeri Singaraja

Wijaya, I K. 2006. Penerapan Penilaian Portofolio dalam Pembelajaran Matematika yang Berbasis Group Investigation (GI) untuk Meningkatkan Kompetensi Dasar Siswa Kelas X3 Semester Genap SMA Laboratorium IKIP Negeri Singaraja Tahun Ajaran 2005/2006. Skripsi. Tidak diterbitkan. Jurusan Pendidikan Matematika, IKIP Negeri Singaraja. 